\title{
Stage IV Primary Vaginal Leiomyosarcoma with Lung and Breast Metastases
}

\author{
Lin Gong $^{\mathrm{a}}$ Hui Liu ${ }^{\mathrm{a}}$ Kai-Xuan Yang ${ }^{\mathrm{b}}$ Zhi-Lan Peng \\ ${ }^{a}$ Department of Obstetrics and Gynecology, \\ ${ }^{b}$ Department of Pathology, West China Second Hospital, West China Center of Medical Sciences, Sichuan University, Chengdu, China
}

\section{Keywords}

Vaginal leiomyosarcoma - Breast metastasis .

Lung metastasis · Neoadjuvant chemotherapy

\section{Summary}

Background: Reproductive tract sarcomas metastasizing to the breast are uncommon. To our knowledge, metastasis of vaginal leiomyosarcoma to the breast has not been previously reported in the literature. Case Report: We present the first report of a FIGO stage IV primary vaginal leiomyosarcoma with metastases to the lung and left breast. Treatment included neoadjuvant chemotherapy followed by surgery and postoperative chemotherapy. Lung metastasis disappeared but recurred 14 months later in conjunction with left breast metastasis which was resected. Conclusion: Primary vaginal sarcoma with lung and breast metastases is very rare in female genital malignancies. We present this case to alert gynecologists to the need for early diagnosis and aggressive management.

\section{Introduction}

Primary vaginal sarcoma accounts for only $1 \%$ of vaginal malignancies which in turn are uncommon among female genital malignancies [1]. The onset age of vaginal sarcoma has 2 peak periods: embryonal rhabdomyosarcoma in children under 5 years and leiomyosarcoma in adults between 30 and 60 years [2]. Until 2006, only 138 cases of vaginal leiomyosarcoma had been reported [3]. We present another rare case of stage IV vaginal leiomyosarcoma with metastases to the lung and breast.

\section{Schlüsselwörter \\ Vaginales Leiomyosarkom · Brustmetastasen . Lungenmetastasen - Neoadjuvante Chemotherapie}

\section{Zusammenfassung}

Hintergrund: Sarkome der Fortpflanzungsorgane metastasieren nur selten in die Brust. Unseres Wissens enthält die Literatur bisher keine Berichte eines in die Brust metastasierten vaginalen Leiomyosarkoms. Fallbericht: Wir berichten erstmals von einem Fall von primärem vaginalen Leiomyosarkom im FIGO-Stadium IV mit Metastasen in Lunge und Brust. Die Behandlung bestand aus neoadjuvanter Chemotherapie gefolgt von Operation und postoperativer Chemotherapie. Die Lungenmetastasen verschwanden, traten aber 14 Monate später gemeinsam mit Metastasen in der linken Brust, die chirurgisch entfernt wurden, erneut auf. Schlussfolgerung: Primäre vaginale Sarkome mit Lungen- und Brustmetastasen sind eine sehr seltene Form bösartiger Tumoren des weiblichen Genitaltrakts. Wir stellen diesen Fall vor, um Gynäkologen auf die Wichtigkeit einer frühen Diagnose und aggressiven Behandlung aufmerksam zu machen.

\section{Case Report}

A 42-year-old woman (gravida 2, para 1) presented with a small lump in the upper left lung and vaginal bleeding in May 2008. The patient had a history of subtotal hysterectomy for hysteromyoma 9 years ago. A needle biopsy of the lump indicated metastatic tumor. A vaginal neoplasm was detected and biopsied in the patient's local Provincial People's Hospital. The histopathological analysis revealed leiomyosarcoma. The patient was transferred to our hospital. Pelvic examination showed an exophytic and ulcerative mass $3 \mathrm{~cm}$ in diameter originating from the lower third of the left vaginal wall. A cervical Pap smear was normal. Pelvic ultrasonography recorded nothing abnormal except uterine absence. The diagnosis was vaginal leiomyosarcoma with pulmonary metastasis.

\section{KARGER \\ Fax +497614520714 \\ Information@Karger.de}

www.karger.com (c) 2012 S. Karger GmbH, Freiburg 1661-3791/12/0072-0150\$38.00/0

Accessible online at: www.karger.com/brc
Professor Zhi-Lan Peng, MD

Department of Obstetrics and Gynecology

West China Second Hospital, Sichuan University

No. 20, Section 3, The People of South Road, 610041, Chengdu, Sichuan, P.R. China

Tel. +86 02885503812

pengzhilan1@163.com 
The patient received preoperative chemotherapy consisting of the MAID regimen (mesna, doxorubicin, ifosfamide, dacarbazine). In June 2008, she underwent extensive excision of the vulva and lower half of the vagina, vulvovaginoplasty, and inguinal and pelvic lymphadenectomy. The gross specimen measured approximately $2 \times 3 \mathrm{~cm}$. Immunohistochemical analysis revealed positive staining for desmin, smooth muscle antibody, and estrogen and progesterone receptors. Ki-67 was positive in $30 \%$ of the neoplastic cells. The pathologic report showed vaginal leiomyosarcoma with necrosis (figs. $1 \mathrm{C}$ and D). Surgical margins were free of disease, and a total of 29 lymph nodes were free of metastasis. After 3 cycles of postoperative MAID chemotherapy, thoracic computed tomography (CT) showed only some remaining fiber shadow. The patient was followed up every 3-4 months.

In February 2010, chest X-ray reported a $3.6 \times 3.5 \mathrm{~cm}$ mass with uneven density near the left pulmonary hilus (fig. 1 A). After 4 months, no change was seen on CT (fig. 1 B), and the oncologists concluded that this was probably a resistant lesion and proposed lobectomy.

In September 2010, the patient palpated a thumbnail mass in her left breast. There were no other breast complaints and no family history of breast cancer. Mammography at the Provincial People's Hospital showed a dense mass measuring $2.2 \times 2 \mathrm{~cm}$ in the upper outer quadrant of the left breast. Examination of a fine needle aspiration revealed suspected fibroadenoma. The patient then accepted segment resection of the left breast and flap reconstruction in that hospital. Immunohistochemistry revealed positive staining for desmin, calponin, and vimentin. Ki-67 was positive in $40 \%$ of the tumor cells. The final pathological diagnosis was leiomyosarcoma. Our hospital supported the diagnosis of metastatic leiomyosarcoma arising from the vagina (fig. $1 \mathrm{E}$ ). The patient was advised to resume MAID. However, after 1 cycle, thoracic CT showed many nodules in both lungs and a cancer embolus in the left atrium, and she was transferred to West China Hospital for palliative treatment.

\section{Discussion}

The present patient underwent a subtotal hysterectomy in another hospital 9 years ago to avoid uterine malignancy. Vaginal bleeding occurred in connection with a vaginal mass. No lumps were noted in other genital organs. Pathological examination at our hospital revealed vaginal leiomyosarcoma, which is a relatively rare and aggressive tumor that spreads early and metastasizes by the hematogenous route. The level of malignancy depends on the histological mitotic activity, cellular atypia, and necrosis. The most frequent symptoms are a growing vaginal mass, abdominal pain, and vaginal bleeding. Due to its extremely aggressive behavior with a great tendency for local recurrence and distant metastasis, the 2-year survival rate is less than $50 \%$ [4]. Although these tumors may occur in relation to pelvic irradiation, the etiology is still unknown [5].

Extensive resection with disease-free margins is the optimal treatment to prevent local recurrence. For persistent or recurrent lesions, postoperative chemotherapy can be added $[6,7]$, but ultimately management should be case-based. MAID is a commonly used regimen. In a meta-analysis including 14 controlled trials, 1,568 patients with soft tissue sarcomas demonstrated that adriamycin-based chemotherapy significantly delayed both local and distant recurrence and enhanced overall recurrence-free survival [8]. Resection of pulmonary metastasis offers a long-term survival benefit [9]. In our case, pre- and postoperative adjuvant chemotherapy made the pulmonary metastasis disappear for 14 months. Detection of the unexpected breast metastasis meant that lung surgery was no longer pursued. Moreover, the patient received 1 cycle of chemotherapy before vaginal leiomyosarcoma surgery, which stopped the bleeding effectively and enabled her to have a successful operation. A recent report of 64 patients with extremity or body wall soft tissue sarcomas characterized by high grade and a diameter of $\geq 8 \mathrm{~cm}$ treated with neoadjuvant chemotherapy (MAID) combined with radiation showed 3-year disease-free and overall survival rates of 56.6 and $75.1 \%$, respectively, and 5-year rates of 56.1 and $71.2 \%$, respectively [10].

The prognostic factors include age, tumor size, histological grade, FIGO stage, mitotic count, tumor injury, and treatment modality. Tumors often relapse within 2 years of the first diagnosis, with hematogenous metastasis to lung or liver [6, 11]. Breast metastasis is very rare $(2 \%)$ because of the large amount of fibrous tissue with relatively poor blood supply making the breast resistant to metastasis from extra-mammary malignancy [12]. Most breast metastases are secondary to lung or other metastases and present as hard, painless, well-circumscribed lumps in the upper outer quadrant without

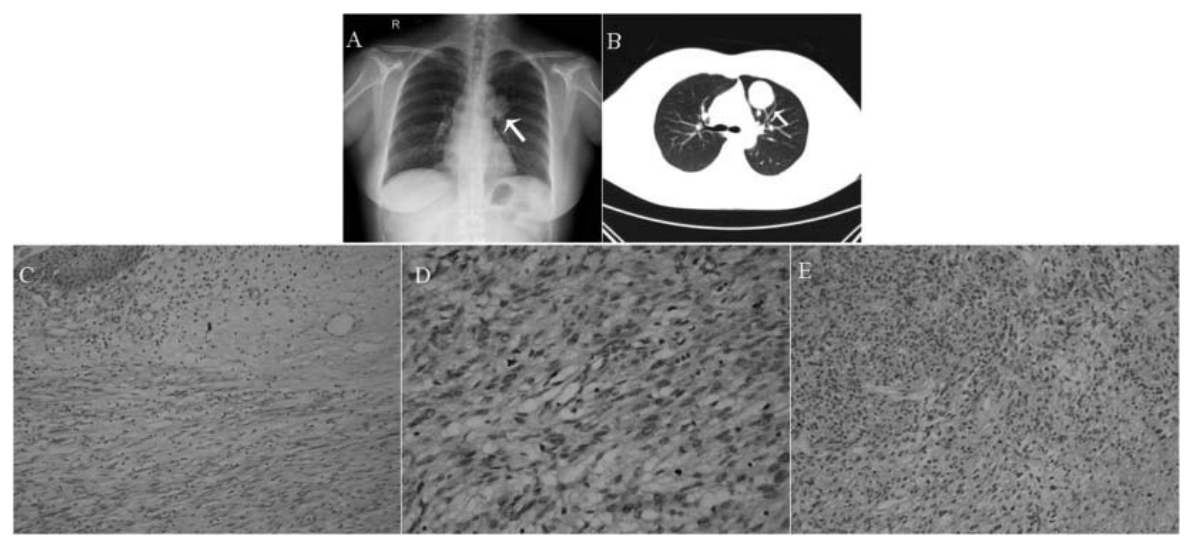

Fig. 1. A $3.6 \times 3.5 \mathrm{~cm}$ mass near the left pulmonary hilus (arrow); B Same mass in computed tomography image 4 months later (arrow); C Vaginal leiomyosarcoma containing interlacing fascicles of spindle cells, many with markedly pleomorphic nuclei, H\&E ×200; D Vaginal leiomyosarcoma cells showing nuclear pleomorphism with bizarre nuclei and mitotic activity, H\&E $\times 400$; E Metastatic breast leiomyosarcoma cells with nucleic mitosis and necrosis, $\mathrm{H} \& \mathrm{E} \times 200$. 
skin change, as described in this report [13, 14]. In our case, the breast metastasis may have been secondary to the lung metastasis. In summary, the rare and prognostically poor tumor form presented in this report requires ongoing evaluation of current therapies and development of new treatment strategies.

\section{Disclosure Statement}

The authors have no conflicts of interest to declare.

\section{References}

1 Benedict JL, Bender H, Jones H, Hacker NF, Ngan HYS, Pecorelli S: FIGO staging classifications and clinical practice guidelines of gynecologic cancers. Int J Gynaecol Obstet 2000;70:209-262.

2 Perez CA, Arneson AN, Galakatos A, Samanth HK: Malignant tumors of the vagina. Cancer 1973;31:36-44.

3 Ahram J, Lemus R, Schiavello HJ: Leiomyosarcoma of the vagina: case report and literature review. Int J Gynecol Cancer 2006;16:884-891.

4 Gadducci A, Cosio S, Romanini A, Genazzani AR: The management of patients with uterine sarcoma: a debated clinical challenge. Crit Rev Oncol Hematol 2008;65:129-142.

5 Miyakawa I, Yasuda H, Taniyama K, Mori R, Uehara Y, Sumiyoshi A: Leiomyosarcoma of the vagina. Int J Gynaecol Obstet 1985;23:213-216.

6 Pautier P, Genestie C, Rey A, Morice P, Roche B, Lhommé C, Haie-Meder C, Duvillard P: Analysis of clinicopathologic prognostic factors for 157 uterine sarcomas and evaluation of a grading score validated for soft tissue sarcoma. Cancer 2000;88:1425-1431.

7 Trovik CS, Bauer HC, Alvegård TA, Anderson H, Blomqvist C, Berlin O, Gustafson P, Saeter G, Wallöe A: Surgical margins, local recurrence and metastasis in soft tissue sarcomas: 559 surgically-treated patients from the Scandinavian Sarcoma Group Register. Eur J Cancer 2000;36:710-716.

$>8$ Tierney JF, Stewart LA, Parmar MKB: Adjuvant chemotherapy for localised resectable soft-tissue sarcoma of adults. Meta-analysis of individual data. Lancet 1997;350:1647-1654.

9 Anderson ML, Bodurka DC: Thoracotomy for the management of recurrent vaginal leiomyosarcoma. Int J Gynecol Cancer 2008;18:188-190.

10 Kraybill WG, Harris J, Spiro IJ, Ettinger DS, DeLaney TF, Blum RH, Lucas DR, Harmon DC, Letson GD, Eisenberg B: Long-term results of a phase 2 study of neoadjuvant chemotherapy and radiotherapy in the management of high-risk, high-grade, soft tissue sarcomas of the extremities and body wall: Radiation Therapy Oncology Group Trial 9514. Cancer 2010;116:4613-4621.

11 Umeadi UP, Ahmed AS, Slade RJ, Menasce LP: Vaginal leiomyosarcoma. J Obstet Gynaecol 2008;28:553-554.

12 Lin $\mathrm{CH}$, Yeh CN, Chen MF: Breast metastasis from uterine leiomyosarcoma: a case report. Arch Gynecol Obstet 2003;267:233-235.

13 Chaignaud B, Hall TJ, Powers C, Subramony C, Scott-Conner CE: Diagnosis and natural history of extramammary tumors metastatic to the breast. J Am Coll Surg 1994;179:49-53.

14 Wood B, Sterrett G, Frost F, Swarbrick N: Diagnosis of extramammary malignancy metastatic to the breast by fine needle biopsy. Pathology 2008;40:345-351. 